\title{
Effect of Rice Husks Concrete Preformed Coffers and Bricks Use on Building Structural Elements
}

\author{
Yawovi Mawuénya Xolali Dany Ayité, Irina Pachoukova, Koffi-Sa Bédja \\ Higher National Engineers School, University of Lome, Lome, Togo \\ Email address: \\ danyayite@gmail.com (Y. M. X. D. Ayité) \\ ${ }^{*}$ Corresponding author \\ To cite this article: \\ Yawovi Mawuénya Xolali Dany Ayité, Irina Pachoukova, Koffi-Sa Bédja. Effect of Rice Husks Concrete Preformed Coffers and Bricks Use \\ on Building Structural Elements. Advances in Materials. Vol. 6, No. 6, 2017, pp. 159-164. doi: 10.11648/j.am.20170606.17
}

Received: November 4, 2017; Accepted: November 16, 2017; Published: December 27, 2017

\begin{abstract}
This article highlights the effect of rice husks concrete preformed coffers and bricks use on building structural elements (joists, beams, columns and footings). For this purpose, $15 \mathrm{~cm}$ thick of preformed coffers, hollow and solid bricks are made from cement - rice husks, cement - rice husks - sand and sand -cement mixtures to determine their characteristics: density, surface weight, brick compressive strength and preformed coffer bending strength. These characteristics were used to calculate building structural elements (joist, beam, column and footing). The results show that the preformed coffers and bricks of rice husks concrete are lighter than those made of sand - cement mortar. The compressive or bending strengths of these elements are similar. The use of rice husks concrete preformed coffers reduces dimensions and reinforcing steels of building structural elements.
\end{abstract}

Keywords: Preformed Coffers, Bricks, Rice Husks Concrete, Compressive Strength, Bending Strength, Beam, Column, Footing

\section{Introduction}

Rice husks concretes are cement, water and rice husks mixture to which sand can be added to improve these concrete characteristics and to reduce the cement dosage [14]. These concretes have for interest, environment protection and rice husks valorization in civil engineering. A lot of work is done to better understand these concretes [1-28]. It turns out that rice husk concretes is a light material with the main disadvantage of cement high dosage. Indeed, to obtain a compressive strength of $10 \mathrm{MPa}$ at 28 days of age, it requires a cement dosage exceeding $700 \mathrm{~kg}$ per meter [3]. Current dosages (between 250 and $500 \mathrm{~kg}$ of cement) resistances are of 1 to $8 \mathrm{MPa}$ order [3]. One of these concretes applications is their use for the manufacture of preformed coffers and bricks used in building [3-4].

The objective of the present study is therefore to determine the characteristics of rice husks concrete preformed coffers and bricks and to analyze the effect of their use on buildings structural elements. Thus, $15 \mathrm{~cm}$ thick preformed coffers and bricks (thickness often used in Togo for the same elements made in sand-cement mortar) are made using cement - rice husks and cement - rice husks - sand mixtures. On these masonry elements, density, surface weight, bricks compressive strength and preformed coffers bending resistance are measured. The structural elements (joist, beam, column and footing) of a building are also calculated.

\section{Materials and Methods}

Rice husks concrete, due to rice husks special characteristic is, at the present stage of research, formulated using experimental method [1-3]. For this study, two types of concrete are selected: cement - rice husks and cement - rice balls - sand mixtures. Rice husks from Kovié Rice Farm, a village located at $27 \mathrm{~km}$ north of Lomé, of which characteristics are shown in Table 1, are mixed with CIMTOGO cement CPJ 35 (one of Togo's cement plants) and drinking water from the TdE (Togolese Water Company) to obtain cement - rice husks mixture. To this mixture, is added sand of Mission Tové quarry, located at $20 \mathrm{~km}$ north of Lomé, presenting characteristics shown in Table 1, to obtain the second type of rice husks concrete. Figure 1 shows rice 
husks and sand grading size curve.

Because of their high absorption rate, rice husks are immersed in water for at least twenty four (24) hours before their use [1-4]. They are then drained to rid them of excess water. Then, rice husks, cement, water and eventually sand are mixed with a mixer for two to three minutes in order to obtain a homogeneous material. The formworks are then filled and compacted using shovels as for sand - cement agglomerates. Release is done immediately since the concrete used is dry.

The constituents' proportions of the two types of rice husks concrete and the sand-cement mortar are presented in
Table 2 [3-4].

Table 1. Characteristics of the materials used.

\begin{tabular}{lll}
\hline Characteristics & Rice husks & Sand \\
\hline Finesse modulus & 3,79 & 1,81 \\
Absorption rate (\%) & 82 & - \\
Apparent density at dry state & 0,101 & - \\
Absolute density at dry state & 0,750 & - \\
Apparent density at wet state & 0,142 & - \\
Absolute density at wet state & 1,050 & - \\
Absolute density & - & 2,58 \\
Apparent density & - & 1,51 \\
Equivalent of sand (\%) & - & 61 \\
\hline
\end{tabular}

Table 2. Material quantity for one concrete cube meter.

\begin{tabular}{|c|c|c|c|c|}
\hline Concrete type & Cement (kg) & Rice husk (kg) & Sand (liters) & Water (liters) \\
\hline Rice husk concrete without sand & 500 & 391 & 0 & 210 \\
\hline Rice husk concrete with sand & 350 & 375 & 100 & 166 \\
\hline Bricks sand - cement mortar & 250 & - & 1000 & 175 \\
\hline Preformed coffers sand - cement mortar & 400 & - & 1000 & 175 \\
\hline
\end{tabular}

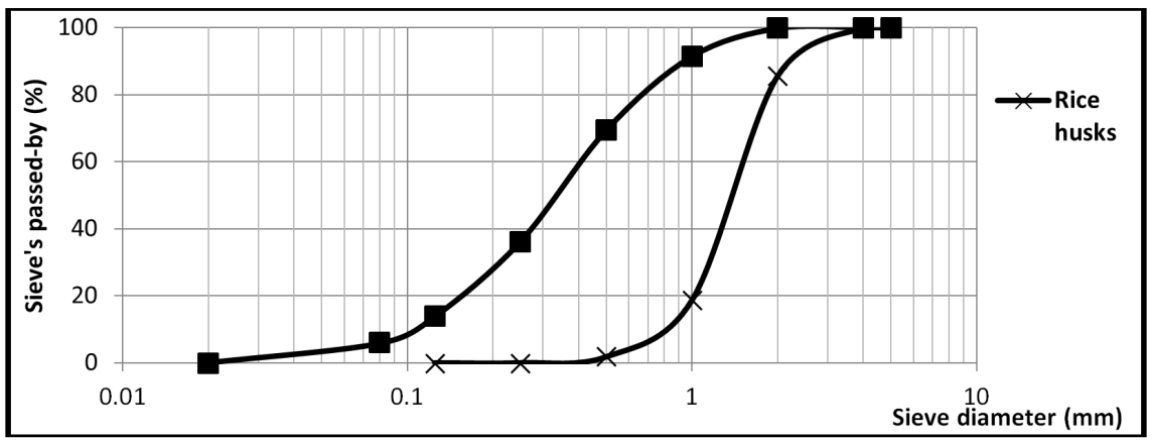

Figure 1. Rice husks and sand grading curve.

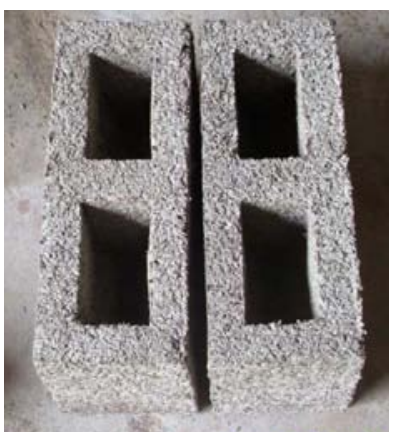

a)

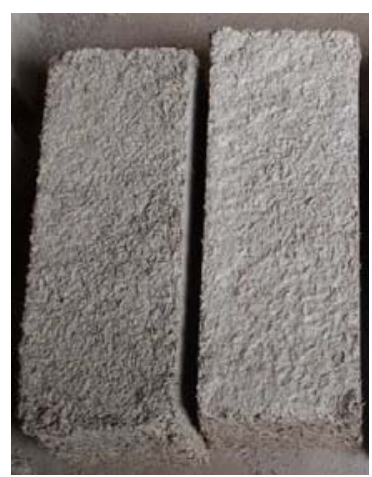

b)

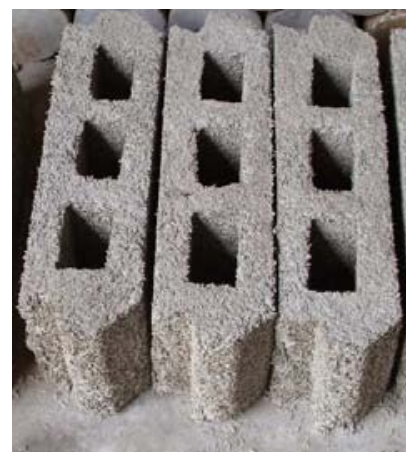

c)

Figure 2. Rice husks concrete hollow (a) and solid (b) bricks and preformed coffer (c).

With these compositions, samples of solid and hollow bricks of $40 \times 20 \times 15 \mathrm{~cm}^{3}$ dimensions as well as preformed coffers of $60 \times 20 \times 15 \mathrm{~cm}^{3}$ dimensions are manufactured. Figure 2 shows an image of solid and hollow bricks and preformed coffers. On these masonry elements, density, surface weight, bricks compressive strength and preformed coffers bending strength are determined at 28 days of age according to the European standard EN 772 [29]. The characteristics of rice husks concrete masonry elements are 
compared with those made with sand - cement mortar, most often used in construction in Togo.

Using the BAEL (Reinforced concrete in the limit states, Béton Armé aux Etats Limites) 91 modified 99 rules [30-31], the dimensioning (geometric dimensions and reinforcement) of a joist, a beam, a column and a pad footing of a two-storey building with hollow pot floor slab is carried out. For this building, two situations are envisaged: at first the preformed coffers are in rice husks concrete with or without sand and in a second time, these elements are in sand-cement mortar. In both cases, the structural elements are made of ordinary reinforced concrete.

\section{Results and Discussion}

Table 3 shows the characteristics of bricks and preformed coffers in rice husks concrete and of those in sand-cement mortar. In this table is also presented the thermal conductivity of concretes and mortars used [3].

Table 3. Bricks and preformed coffers characteristics.

\begin{tabular}{llll}
\hline Masonry type & Density $\left(\mathbf{g} / \mathbf{c m}^{\mathbf{3}}\right)$ & Surface weight $\left(\mathbf{N} / \mathbf{m}^{\mathbf{2}}\right)$ & Compressive strength at 28 days of age $(\mathbf{M P a})$ \\
\hline Rice husks concrete without sand solid brick & 0.98 & 1480 & 1.26 \\
Rice husks concrete with sand solid bricks & 0.95 & 1385 & 2.0 \\
Sand-cement mortar solid bricks & 1.39 & 2090 & 1.29 \\
Rice husks concrete without sand hollow bricks & 1.04 & 1090 & 1.03 \\
Rice husks concrete with sand hollow bricks & 1.00 & 1020 & 1.52 \\
Sand-cement mortar hollow bricks & 1.93 & 1970 & 0.93 \\
Rice husks concrete without sand preformed coffer & 0.90 & 1100 & - \\
Rice husks concrete with sand preformed coffer & 0.85 & 1030 & - \\
Sand-cement mortar preformed coffer & 1.68 & 1800 & - \\
\hline
\end{tabular}

Table 3. Continued.

\begin{tabular}{lll}
\hline Masonry type & Bending strength at 28 days of age (MPa) & Thermal conductivity (W/m. K.) \\
\hline Rice husks concrete without sand solid brick & - & - \\
Rice husks concrete with sand solid bricks & - & 0.638 \\
Sand-cement mortar solid bricks & - & 0.477 \\
Rice husks concrete without sand hollow bricks & - & 1.30 \\
Rice husks concrete with sand hollow bricks & - & 0.638 \\
Sand-cement mortar hollow bricks & 2.99 & 0.477 \\
Rice husks concrete without sand preformed coffer & 2.06 & 1.30 \\
Rice husks concrete with sand preformed coffer & 2.34 & 0.638 \\
Sand-cement mortar preformed coffer & & 0.477 \\
\hline
\end{tabular}

By analyzing the data in Table 3, it appears that:

- compressive strengths of rice husk concrete bricks and sand - cement bricks are of the same order of magnitude with a slight dominance of rice husks bricks;

- rice husks concrete without sand bricks and preformed coffers consume more cement than sand-cement agglomerates; sand dosage makes it possible to reduce the cement dosage and to improve the resistance;

- rice husks concrete bricks and preformed coffers are lighter than those made of sand - cement mortar: there is a decrease in mass of about $46 \%$; this lightness will contribute to reduce building permanent loads thus to obtain economical foundations;

- rice husks with sand preformed coffer bending strength is close to that of sand-cement preformed coffer while -that of rice husk without sand preformed coffers is 1.3 times higher: there is an increase in resistance of about $30 \%$;

- rice husks concrete are more heat-resistant (lower thermal conductivity) than sand-cement mortar: rice husks concrete preformed coffers and bricks will provide better thermal insulation.

Table 4 presents loads and materials characteristics used to size considered elements.

Table 4. Dimensioning Data.

\begin{tabular}{lll}
\hline Designation & $\begin{array}{l}\text { Rice husks concrete without sand } \\
\text { preformed coffer }\end{array}$ & $\begin{array}{l}\text { Rice husks concrete with } \\
\text { sand preformed coffer }\end{array}$ \\
Floor: & $\begin{array}{l}\text { Sand-cement mortar } \\
\text { preformed coffer }\end{array}$ & $1.25 \mathrm{kN} / \mathrm{m}^{2}$ \\
- Dead loads: & $1.25 \mathrm{kN} / \mathrm{m}^{2}$ & $1.125 \mathrm{kN} / \mathrm{m}^{2}$ \\
Compressive slab & $1.125 \mathrm{kN} / \mathrm{m}^{2}$ & $1.03 \mathrm{kN} / \mathrm{m}^{2}$ \\
Joist & $1.1 \mathrm{kN} / \mathrm{m}^{2}$ & $0.8 \mathrm{kN} / \mathrm{m}^{2}$ \\
Preformed coffer & $0.8 \mathrm{kN} / \mathrm{m}^{2}$ & $0.2 \mathrm{kN} / \mathrm{m}^{2}$ \\
Cement screed & $0.2 \mathrm{kN} / \mathrm{m}^{2}$ & $4.405 \mathrm{kN} / \mathrm{m}^{2}$ \\
Under slab cement rendering & $4.475 \mathrm{kN} / \mathrm{m}^{2}$ & $1.5 \mathrm{kN} / \mathrm{m}^{2}$ \\
Total dead loads & $1.5 \mathrm{kN} / \mathrm{m}^{2}$ & $20 \mathrm{MPa}$ \\
- Working loads & $20 \mathrm{MPa}$ & $\mathrm{Fe} \mathrm{E} 400$ \\
Concrete compressive strength at 28 days of age & $\mathrm{Fe} \mathrm{E} 400$ & $0.125 \mathrm{kN} / \mathrm{m}^{2}$ \\
Grade of steel for longitudinal reinforcement & & $5.175 \mathrm{kN} / \mathrm{m}^{2}$ \\
\hline
\end{tabular}


It appears from this table that floor made with sand-cement mortar preformed coffers is heavier than floor made with rice husks concrete preformed coffers. There is a decrease in weight of $13 \%$ to $15 \%$ depending on whether rice husk concrete is dosed with sand or not.

Tables 5 and 6 present joist and beam calculation results. The joist is simply supported at his extremities and has a span of $3 \mathrm{~m}$. The beam is a continuous beam, simply supported with two spans of respective $4.5 \mathrm{~m}$ and $4 \mathrm{~m}$.

Table 5. Joist calculation result.

\begin{tabular}{|c|c|c|c|}
\hline Designation & $\begin{array}{l}\text { Rice husks concrete without } \\
\text { sand preformed coffer }\end{array}$ & $\begin{array}{l}\text { Rice husks concrete with } \\
\text { sand preformed coffer }\end{array}$ & $\begin{array}{l}\text { Sand-cement mortar } \\
\text { preformed coffer }\end{array}$ \\
\hline \multicolumn{4}{|l|}{ Dimensions: } \\
\hline Length (L): & $3 \mathrm{~m}$ & $3 \mathrm{~m}$ & $3 \mathrm{~m}$ \\
\hline Width (b): & $10 \mathrm{~cm}$ & $10 \mathrm{~cm}$ & $10 \mathrm{~cm}$ \\
\hline Depth (h): & $20 \mathrm{~cm}$ & $20 \mathrm{~cm}$ & $20 \mathrm{~cm}$ \\
\hline Effective depth (d): & $16 \mathrm{~cm}$ & $16 \mathrm{~cm}$ & $16 \mathrm{~cm}$ \\
\hline Dead loads: & $2,685 \mathrm{kN} / \mathrm{m}$ & $2,643 \mathrm{kN} / \mathrm{m}$ & $3,105 \mathrm{kN} / \mathrm{m}$ \\
\hline Working loads: & $0,9 \mathrm{kN} / \mathrm{m}$ & $0,9 \mathrm{kN} / \mathrm{m}$ & $0,9 \mathrm{kN} / \mathrm{m}$ \\
\hline Dead loads bending moment $\left(\mathrm{M}_{\mathrm{G}}\right)$ : & $3,021 \mathrm{kNm}$ & $2,973 \mathrm{kNm}$ & $3,493 \mathrm{kNm}$ \\
\hline Working loads bending moment $\left(\mathrm{M}_{\mathrm{Q}}\right)$ : & $1,013 \mathrm{kNm}$ & $1,013 \mathrm{kNm}$ & $1,013 \mathrm{kNm}$ \\
\hline Bending moment at ultimate limit state $\left(\mathrm{M}_{\mathrm{u}}=1,35 \mathrm{M}_{\mathrm{G}}+1,5 \mathrm{M}_{\mathrm{Q}}\right)$ : & $5,598 \mathrm{kNm}$ & $5,533 \mathrm{kNm}$ & $6,235 \mathrm{kNm}$ \\
\hline Bending moment at serviceability limit state $\left(\mathrm{M}_{\mathrm{ser}}=\mathrm{M}_{\mathrm{G}}+\mathrm{M}_{\mathrm{Q}}\right)$ : & $4,034 \mathrm{kNm}$ & $3,986 \mathrm{kNm}$ & $4,506 \mathrm{kNm}$ \\
\hline Reinforcement section & $1,51 \mathrm{~cm}^{2}$ & $1,51 \mathrm{~cm}^{2}$ & $2,07 \mathrm{~cm}^{2}$ \\
\hline
\end{tabular}

From this table, it appears that all joists require the same concrete amount despite their weight difference. Indeed, this difference is small to influence concrete amount. The reinforcements of the joists supporting rice husks concrete preformed coffers are inferior to those of the joists supporting sand-cement mortar preformed coffers. Admittedly, these preformed coffers are about 1.6 times heavier than those made of rice husks concrete which results in an increase of joist reinforcement of the order of $37 \%$.

Table 6. Beam calculation result.

\begin{tabular}{llll}
\hline Designation & $\begin{array}{l}\text { Rice husks concrete without } \\
\text { sand preformed coffer }\end{array}$ & $\begin{array}{l}\text { Rice husks concrete with sand } \\
\text { preformed coffer }\end{array}$ & $\begin{array}{l}\text { Sand-cement mortar } \\
\text { preformed coffer }\end{array}$ \\
\hline Dimensions: & $15 \mathrm{~cm}$ & $15 \mathrm{~cm}$ & $15 \mathrm{~cm}$ \\
Width (b): & $50 \mathrm{~cm}$ & $50 \mathrm{~cm}$ & $50 \mathrm{~cm}$ \\
Depth (h): & $45 \mathrm{~cm}$ & $45 \mathrm{~cm}$ & $45 \mathrm{~cm}$ \\
Effective depth (d): & $1,875 \mathrm{kN} / \mathrm{m}$ & $1,875 \mathrm{kN} / \mathrm{m}$ & $1,875 \mathrm{kN} / \mathrm{m}$ \\
Beam weight: & $13,425 \mathrm{kN} / \mathrm{m}$ & $13,215 \mathrm{kN} / \mathrm{m}$ & $15,525 \mathrm{kN} / \mathrm{m}$ \\
Floor dead load & $5,516 \mathrm{kN} / \mathrm{m}$ & $5,516 \mathrm{kN} / \mathrm{m}$ & $5,516 \mathrm{kN} / \mathrm{m}$ \\
Wall weight (Pm) & $4,5 \mathrm{kN} / \mathrm{m}$ & $4,5 \mathrm{kN} / \mathrm{m}$ & $4,5 \mathrm{kN} / \mathrm{m}$ \\
Floor working load & $34,85 \mathrm{KN} / \mathrm{m}$ & $34,57 \mathrm{kN} / \mathrm{m}$ & $37,69 \mathrm{kN} / \mathrm{m}$ \\
Loads at ultimate limit state & $25,32 \mathrm{kN} / \mathrm{m}$ & $25,11 \mathrm{kN} / \mathrm{m}$ & $27,42 \mathrm{kN} / \mathrm{m}$ \\
Loads at serviceability limit state & & & \\
Span N 1; Length = 4,50 m & $57,15 \mathrm{kNm}$ & $56,71 \mathrm{kNm}$ & $61,61 \mathrm{kNm}$ \\
Moment at mid-span at ultimate limit state & $41,37 \mathrm{kNm}$ & $41,04 \mathrm{kNm}$ & $44,68 \mathrm{kNm}$ \\
Moment at mid-span at serviceability limit state & $5,40 \mathrm{~cm}^{2}$ & $5,40 \mathrm{~cm}$ & $5,75 \mathrm{~cm}^{2}$ \\
Reinforcement section & & & \\
Span N 2; Length = m & $40,49 \mathrm{kNm}$ & $40,19 \mathrm{kNm}$ & $43,52 \mathrm{kNm}$ \\
Moment at mid-span at ultimate limit state & $29,22 \mathrm{kNm}$ & $28,99 \mathrm{kNm}$ & $31,47 \mathrm{kNm}$ \\
Moment at mid-span at serviceability limit state & $3,83 \mathrm{~cm}^{2}$ & $3,83 \mathrm{~cm}^{2}$ & $3,93 \mathrm{~cm}^{2}$ \\
Reinforcement section & & & \\
Intermediate support & $74,83 \mathrm{kNm}$ & $74,22 \mathrm{kNm}$ & $80,93 \mathrm{kNm}$ \\
Moment at support at ultimate limit state & $54,35 \mathrm{kNm}$ & $53,90 \mathrm{kNm}$ & $58,87 \mathrm{kNm}$ \\
Moment at support at serviceability limit state & $6,98 \mathrm{~cm}^{2}$ & $6,98 \mathrm{~cm}^{2}$ & $7,60 \mathrm{~cm}^{2}$ \\
Reinforcement section & & \\
\hline
\end{tabular}

The results of this table confirm the lightness of the floors made of rice husks concrete preformed coffers compared to those with sand-cement mortar preformed coffers. At equal section, beams supporting rice husks concrete preformed coffers are the least loaded and therefore require less reinforcement. There is a decrease in the amount of reinforcement of beam supporting rice husks concrete preformed coffers about $7 \%$ compared to that receiving sandcement mortar preformed coffers.
Tables 7 and 8 show column and pad footing calculation result.

From these tables, it appears that rice husks concrete preformed coffers building column is the least loaded and therefore the least reinforced. The use of the rice husks concrete preformed coffers allows column reinforcement reduction of the order of $40 \%$. Similarly, this use allows a reduction of pad footing dimensions of $10 \%$, a reduction of $17 \%$ of concrete volume. The pad footing reinforcement 
amount is reduced by $20 \%$.

preformed coffers use on building structural elements.

Table 9 summarizes the impact of rice husk concrete

Table 7. Column calculation result.

\begin{tabular}{lll}
\hline Designation & $\begin{array}{l}\text { Rice husks concrete without sand } \\
\text { preformed coffer }\end{array}$ & $\begin{array}{l}\text { Rice husks concrete with sand } \\
\text { preformed coffer }\end{array}$ \\
\hline Ground floor level & & $\begin{array}{l}\text { Sand-cement mortar } \\
\text { preformed coffer }\end{array}$ \\
Dimensions: & $3 \mathrm{~m}$ & $3 \mathrm{~m}$ \\
Height: & $15 \mathrm{~cm}$ & $15 \mathrm{~cm}$ \\
Length: & $15 \mathrm{~cm}$ & $15 \mathrm{~cm}$ \\
Width: & $1,575 \mathrm{kN}$ & $1,575 \mathrm{kN}$ \\
Column weight & $170,33 \mathrm{kN}$ & $168,96 \mathrm{kN}$ \\
Load at ultimate limit state from beam & $136,06 \mathrm{kN}$ & $15 \mathrm{~cm}$ \\
Effort from upper floor (kN) & $308,52 \mathrm{kN}$ & $15 \mathrm{~cm}$ \\
Effort in column at ultimate limit state & $6,16 \mathrm{~cm}^{2}$ & $305,79 \mathrm{kN}$ \\
Reinforcement section & & $6,16 \mathrm{~cm}^{2}$ \\
\hline
\end{tabular}

Table 8. Pad footing calculation result.

\begin{tabular}{lll}
\hline Designation & $\begin{array}{l}\text { Rice husks concrete without } \\
\text { sand preformed coffer }\end{array}$ & $\begin{array}{l}\text { Rice husks concrete with sand } \\
\text { preformed coffer }\end{array}$ \\
\hline Effort from column & $308,52 \mathrm{kN}$ & $\begin{array}{l}\text { Sand-cement mortar } \\
\text { preformed coffer }\end{array}$ \\
Sub-grade allowable stress: & $0,35 \mathrm{MPa}$ & $305,79 \mathrm{kN}$ \\
Dimensions: & & $0,35 \mathrm{MPa}$ \\
Length: & $100 \mathrm{~cm}$ & $100 \mathrm{~cm}$ \\
Width: & $100 \mathrm{~cm}$ & $100 \mathrm{~cm}$ \\
Height: & $30 \mathrm{~cm}$ & $30 \mathrm{~cm}$ \\
Reinforcement in length direction & $4,02 \mathrm{~cm}^{2}$ & $4,02 \mathrm{~cm}^{2}$ \\
Reinforcement in width direction & $4,02 \mathrm{~cm}^{2}$ & $4,02 \mathrm{~cm}^{2}$ \\
\hline
\end{tabular}

Table 9. Comparison of structural elements for the three types of preformed coffers.

\begin{tabular}{|c|c|c|c|c|}
\hline Designation & Rice husks concrete (A) & Sand-cement mortar (B) & Rate $(\mathbf{A} / \mathbf{B})$ & Variation rate $(\%)((B-A) / B)$ \\
\hline Floor weight $\left(\mathrm{kN} / \mathrm{m}^{2}\right)$ & $4,405-4,475$ & 5,175 & $0,85-0,86$ & $13,5-14,8$ \\
\hline Joist concrete $\left(\mathrm{m}^{3}\right)$ & 0,06 & 0,06 & 1 & 0 \\
\hline Joist reinforcement $\left(\mathrm{cm}^{2}\right)$ & 1,51 & 2,07 & 0,73 & 27 \\
\hline Beam reinforcement $\left(\mathrm{cm}^{2}\right)$ & 16,21 & 17,28 & 0,93 & 6,2 \\
\hline Column concrete $\left(\mathrm{m}^{3}\right)$ & 0,135 & 0,135 & 1 & 0 \\
\hline Column reinforcement $\left(\mathrm{cm}^{2)}\right.$ & 6,16 & 12,57 & 0,49 & 51 \\
\hline Pad footing reinforcement $\left(\mathrm{cm}^{2}\right)$ & 8,04 & 10,06 & 0,80 & 20,1 \\
\hline
\end{tabular}

The impact of rice husk concrete preformed coffers use is felt on all structural elements, especially at columns and footings level. This impact results in a decrease of concrete and reinforcement quantities of structural elements.

\section{Conclusion}

This work aims to study the effect of rice husks concrete (with or without sand) preformed coffers and bricks use in the realization of buildings structural elements (joist, beam, column and footing).

The determination of preformed coffers and bricks characteristics has shown that these masonry elements made with rice husks concrete are lighter and as resistant (even more) than those made with sand-cement mortars commonly used in Togo. They also have better thermal conductivity and therefore good thermal insulation. The lightest and most resistant elements are obtained with rice husks concrete dosed with sand: compared to cement-sand mortar elements, one obtains a weight gain of about $46 \%$ and a resistance increase of $30 \%$.
The dimensioning a two-storey building with hollow pot floor slab structural elements has shown that rice husks concrete preformed coffers use has the advantage of reducing the dimensions and reinforcement of structural elements. In fact, compared to floor made with sand-cement mortar preformed coffers, rice husks concrete preformed coffers permit a reducing of floor weight $(30 \%)$, footing concrete $(15 \%)$ and joist, beam, column and footing reinforcement (from $6 \%$ to $51 \%$ ).

\section{References}

[1] AYITE D., NEGLO K., BIGAH Y. \& BEDJA K., Influence of sand dosage on strengths of concretes based on rice husks from Togo. J. Rech. Sci. Univ. Lomé (Togo), Série E, 9 (2), (2007), 57-64.

[2] AYITE Y. M. X. D., NEGLO K., ZIDOL A. \& BEDJA K., Influence of Water/Cement ratio $(\mathrm{W} / \mathrm{C})$ on rice husks concretes resistance of Togo. JSPI, Dakar, Senegal, 13, (2011), 23-28. 
[3] AYITE Y. M. X. D., Rice husks concretes uses for buildings floors preformed coffers prefabrication (Unpublished doctoral dissertation). Doctorate Thesis. University of Lome, Togo. (2011).

[4] AYITE Y. M. X. D., KODJO K. M. \& BEDJA K., Determination of rice husks concrete application in building in Togo. J. Rech. Sci. Univ. Lomé (Togo), Série E, 13 (2) (2011), 1-8.

[5] MANNAN M. A. and GANAPATHY C., Engineering properties of concrete with OPS as aggregate. International Journal of Construction and Building Materials, 16, (2000), 29-34.

[6] MANNAN M. A. and GANAPATHY C., Mix design for oil palm shell concrete. International Journal of Cement and Concrete Research, 31, (2001), 1323-1325.

[7] MANNAN M. A. and GANAPATHY C., Long-term strengths of concrete with oil palm shell as coarse aggregate. International Journal of Cement and Concrete Research, 16, (2001), 1319-1321.

[8] MANNAN M. A and GANAPATHY C., Concrete from an agricultural waste-oil palm shell (OPS). Building and Environment, 39, (2004), 441-448.

[9] JAUBERTHIE Raoul, RENDELL Frank, TAMBA Séni \& CISSE Ibrahima Khalil, Origin of the pouzzolanic effect of rice husk. International Journal of Construction and Building Materials, 14, (2000), 419-423.

[10] JAUBERTHIE Raoul, RENDELL Frank, TAMBA Séni \& CISSE Ibrahima Khalil, Properties of cement - Rice husk mixture. International Journal of Construction and Building Materials, 17, (2003), 239-243.

[11] Alaa Rashad, Cementitious materials and agricultural wastes as natural fine aggregate replacement in conventional mortar and concrete, Journal of Building Engineering, Volume 5, (2016), 119-141.

[12] D. Koňáková et al., "Influence of Moisture Content on the Thermal Properties of Concrete Containing Agricultural Waste Materials", Key Engineering Materials, Vol. 677, (2016), 241-245.

[13] Singh Gurmit, Arora Amit, Singh Ranjeet, Tyagi Anand K., Utilisation of Agricultural Waste Material as Aggregates in Partial Replacement of Coarse Aggregates in the Conventional Concrete, Journal of Biofuels and Bioenergy, Volume: 2, Issue: 1, (2016), 67-72.

[14] Alireza Javadi Pordesari, Salmaliza Salleh, Payam Shafigh and Hilmi Bin Mahmuda, Toward Sustainability in Concrete Industry by Using Of Solid Wastes from Palm Oil Industry, MATEC Web of Conferences Volume 66, 00099 (2016), The 4th International Building Control Conference 2016 (IBCC 2016).

[15] Javad Nodeh Farahani, Payam Shafigh, Hilmi Bin Mahmud, Production of a green lightweight aggregate concrete by incorporating high volume locally available waste materials, Procedia Engineering, Volume 184, (2017), 778-783.

[16] Payam Shafigh, Hilmi Bin Mahmud, Mohd Zamin Jumaat, Majid Zargar, Agricultural wastes as aggregate in concrete mixtures - A review, Construction and Buldung Materials, 53, (2014), 110-117.
[17] Jnyanendra Kumar Prusty, Sanjaya Kumar Patro, S. S. Basarkar, Concrete using agro-waste as fine aggregate for sustainable built environment - A review, International Journal of Sustainable Built Environment, 5, (2016), 312-333.

[18] K. Gunasekaran, R. Annadurai, and P. S. Kumar, "Study on reinforced lightweight coconut shell concrete beam behavior under flexure," Materials and Design, vol. 46, (2013), 157167.

[19] B. S. Mohammed, W. L. Foo, and M. Abdullahi, "Flexural strength of palm oil clinker concrete beams," Materials and Design, vol. 53, (2014) 325-331.

[20] J. Kanadasan and H. A. Razak, "Mix design for selfcompacting palm oil clinker concrete based on particle packing," Materials and Design, vol. 56, (2014) 9-19.

[21] A. Charif, M. J. Shannag, and S. Dghaither, "Ductility of reinforced lightweight concrete beams and columns," Latin American Journal of Solids and Structures, vol. 11, no. 7, (2014) 1251-1274.

[22] K. Gunasekaran, R. Ramasubramani, R. Annadurai, and S. Prakash Chandar, "Study on reinforced lightweight coconut shell concrete beam behavior under torsion," Materials and Design, vol. 57, (2014) 374-382.

[23] S. P. Yap, C. H. Bu, U. J. Alengaram, K. H. Mo, and M. Z. Jumaat, "Flexural toughness characteristics of steelpolypropylene hybrid fibre-reinforced oil palm shell concrete," Materials and Design, vol. 57, (2014) 652-659.

[24] K. H. Mo, K. K. Q. Yap, U. J. Alengaram, and M. Z. Jumaat, "The effect of steel fibres on the enhancement of flexural and compressive toughness and fracture characteristics of oil palm shell concrete," Construction and Building Materials, vol. 55, (2014) 20-28.

[25] K. H. Mo, S. P. Yap, U. J. Alengaram, M. Z. Jumaat, and C. $\mathrm{H}$. Bu, "Impact resistance of hybrid fibre-reinforced oil palm shell concrete," Construction and Building Materials, vol. 50, (2014), 499-507.

[26] K.-S. Youm, J. J. Kim, and J. Moon, "Punching shear failure of slab with lightweight aggregate concrete (LWAC) and low reinforcement ratio," Construction and Building Materials, vol. $65,(2014), 92-102$.

[27] U. Johnson Alengaram, B. A. Al Muhit, M. Z. bin Jumaat, and M. L. Y. Jing, "A comparison of the thermal conductivity of oil palm shell foamed concrete with conventional materials," Materials and Design, vol. 51, (2013) pp. 522-529.

[28] Soudagar Ahemad Mohamadali, Effect on properties of concrete using agro-west as replacement of sand, International Research Journal of Engineering and Technology, Volume: 04 Issue: 06, (2017), 2410-2414.

[29] European Standards CSN EN 772, Methods of test for masonry units, (2015).

[30] HUSSON J.-M., Study of concrete structures (BAEL 91 revised 99), Etude des structures en béton (BAEL 91 revisé 99)", Casteilla, Paris-France, 2002.

[31] Jean PERCHAT and Jean ROUX, Practice of BAEL 91courses with corrected exercises, Pratique du BAEL 91 cours avec exercices corrigés, Eyrolles, ISBN: 2-212-11049-9, 2002. France. 